\title{
Upaya membentuk prilaku peduli lingkungan dan tanggung jawab siswa perspektif manajemen strategi di MA Darussalam Ngesong
}

\author{
Achmad Junaidi a,1,* \\ a Universitas Islam Negeri Maulana Malik Ibrahim, Jl. Gajayana No. 50 Dinoyo Lowokwaru, Malang, Indonesia \\ 1 ajunaidi7781@gmail.com \\ * corresponding author
}

\section{ARTICLE INFO}

\section{Article History}

Received: 29 of March 2021

Revised: 13 of August 2021

Accepted: 16 of August 2021

Keyword: Environmental Awareness, Student Responsibility, Strategic Management

\begin{abstract}
This study aims to describe the efforts made by Madrasah Aliyah Darussalam Sengon Jombang in shaping environmental awareness and student responsibility behavior with a strategic management perspective. These two values are important to be internalized in students, as an effort to build character. This research was conducted using a qualitative research approach, descriptive research type. The data in this study were collected from informants and field data, the techniques used were interviews and observations. Data analysis was carried out through the process of data reduction, data presentation, and data verification which were carried out interactively. The results showed that efforts to shape environmental care and responsibility behavior were carried out by means of Kresekisasi activities. Kresekisasi is a strategy realization of the pesantren's vision, which is noble in character and superior in achievement in responding to the external and internal environmental conditions of the pesantren. The realization of activities is carried out by implementing a strategic process consisting of information and data collection, strategy development, strategy implementation, and measurement and assessment of results.
\end{abstract}

\section{ABSTRAK}

Penelitian ini bertujuan untuk mendeskripsikan upaya yang dilakukan oleh Madrasah Aliyah Darussalam Sengon Jombang dalam membentuk prilaku peduli lingkungan dan tanggungjawab dengan perspektif manajemen strategi. Kedua nilai tersebut penting untuk diinternalisasikan pada peserta didik, sebagai upaya pembentukan karakter. Penelitian ini dilakukan dengan menggunakan pendekatan penelitian kualitatif, jenis penelitian deskriptif. Data pada penelitian ini dikumpulkan dari informan dan data lapangan, teknik yang digunakan yaitu wawancara dan observasi. Analisis data dilakukan melalui proses reduksi data, penyajian data, dan verifikasi data yang dilakukan secara interaktif. Hasil penelitian menunjukkan bahwa upaya membentuk prilaku peduli lingkungan dan tanggungjawab dilakukan dengan kegiatan Kresekisasi. Kresekisasi merupakan realisasi strategi dari visi pesantren yaitu mulia dalam budi pekerti dan unggul dalam prestasi dalam menanggapi kondisi lingkungan eksternal dan internal pesantren. Realisasi kegiatan dilakukan dengan mengimplementasikan proses strategis yang terdiri dari pengumpulan informasi dan data, pengembangan strategi, implementasi strategi, dan pengukuran serta penilaian hasil.

This is an open access article under the $\mathrm{CC}-\mathrm{BY}-\mathrm{SA}$ license. 


\section{Introduction (Heading 1) (bold, 11 pt)}

Prilaku peduli lingkungan disertai tanggungjawab yang tinggi, masih menjadi permasalahan yang serius untuk dicari dan diberikan solusi bagi warga sekolah atau madrasah. Sebagai contoh, adalah kepedulian terhadap lingkungan yang bersih, yang merupakan harapan yang menjadi cita-cita bersama untuk diwujudkan. Prilaku menjaga kebersihan dengan membuang sampah pada tempatnya belum menjadi habituasi yang bertolak belakang dengan pendidikan, bil khusus pendidikan karakter dan pendidikan agama Islam. Jargon an-Nadzaafatu min-l-iman sudah menjadi pengetahuan kognisi, namun belum menjadi bagian dari prilaku hidup dan kehidupan yang seharusnya menjadi driving force atau penggerak utama dalam hidup bersama.

Indeks Perlindungan Lingkungan atau yang dikenal dengan Environment Protection Index (EPI) pada tahun 2019 mempublikasikan laporannya, yang menyatakan bahwa negara terbersih sedunia adalah Switzerland. Adapun Indonesia, berada pada peringkat 133 dari 180 negara yang menjadi subjek survey. Kondisi yang demikian itu merupakan tantangan untuk dicari dan diberikan jawaban yang konkrit menurut kapasitas masing-masing warga negara.

Tidak dapat dipungkiri bahwa prilaku hidup bersih, peduli lingkungan, disertai tanggungjawab merupakan faktor utama dalam mewujudkan kesehatan pada semua lokasi. Tiga hal tersebut dapat dilaksanakan dari rasa tanggungjawab individu dan warga masyarakat. Rasa peduli untuk membangun karakter tanggungjawab membutuhkan kejelasan sistematika program dari mulai tujuan, sistem, hingga evaluasi yang terstruktur dan terarah untuk mewujudkan perecanaan yang dirumuskan.

Lembaga pendidikan memiliki peran yang signifikan dalam menjawab tantangan tersebut, dengan alasan pendekatan sistim yang saling terkait antara tujuan atau visi-misi sekolah, kurikulum, dan berbagai perangkat pendidikan dapat dikembangkan untuk memberi bekal pengetahuan, keterampilan, dan kemampuan peserta didik. Madrasah atau sekolah merupakan tempat yang representatif untuk menyemai, menebar bibit-bibit karakter, menumbuhkan, mengajarkan, dan membangun kebiasaan prilaku hidup bersih secara sadar dan bertanggungjawab.

Penelitian yang dilakukan oleh Mukminin (2014) menyebutkan upaya sekolah dalam membentuk karakter peduli lingkungan pada sekolah Adiwiyata dilakukan dengan pola empat pilar pembentukan karakter; kegiatan belajar mengajar, mengelola budaya sekolah, menjalankan kegiatan ekstrakulikuler, dan penguatan orang tua terhadap siswa. Implementasi empat pilar tersebut berlaku pada seluruh siswa dengan kegiatan-kegiatan aplikatif piket kebersihan kelas dan lingkungan sekolah, integrasi karakter peduli lingkungan pada rencana pembelajaran, dan beberapa kegiatan bersifat spontanitas [1]. Senada dengan hal tersebut Rosyad (2019) mengemukakan bahwa pendidikan karakter melalui elemen lingkungan dilakukan dengan keteladanan, intervensi, pembiasaan yang dilakukan secara konsisten dengan penguatan [2].

Aditia dkk. memberikan fokus pada kegiatan sebagai representasi aplikatif dari pembentukan karakter peduli lingkungan pada sekolah Adiwiyata untuk membedakan prilaku warga sekolah di desa dan warga sekolah di kota. Dicontohkan program yang terlaksana dan berdampak yaitu; kebersihan kelas, pengelolaan air, pengelolaan sumber daya energi, pengelolaan sampah, dan peduli terhadap lingkungan sekitar. Hasil penelitian tersebut menunjukkan bahwa ada perbedaan prilaku peduli lingkungan warga desa dan masyarakat kota. Perbedaan tersebut disebabkan oleh faktor geografis dan ketersediaan sarana dan prasarana[3]. Ardianti (2017) memberikan model pembentukan prilaku peduli lingkungan yang disebut EJAS singkatan dari Experiensial Jelajah Alam Sekitar menggunakan pendekatan science edutainment. Dengan model pembentukan prilaku ini, disebutkan bahwa siswa menjadi lebih senang, lebih peduli, dan memiliki rasa tanggungjawab terhadap lingkungan sekitarnya [4].

Berdasarkan observasi partisipan yang dilakukan oleh peneliti, ditemukan bahwa beberapa siswa dan warga sekolah belum menyadari urgensi dari kepedulian terhadap lingkungan berikut peran dan tanggungjawabnya. Demikian itu ditunjukkan dengan sikap acuh tak acuh terhadap kebersihan lingkungan, membersihkan kelas atau kamar berdasarkan perintah, serta tingkat pengawasan yang tinggi dan berulang-ulang. Oleh karena itu, menarik bagi peneliti untuk melakukan penelitian upaya yang dilakukan dalam membentuk prilaku tersebut dengan pendekatan manajemen strategis. 
Madrasah Aliyah Darussalam Sengon Jombang memiliki visi "Mulia dalam budi pekerti, dan unggul dalam prestasi". Untuk mewujudkan visi tersebut, madrasah memiliki tantangan dalam membentuk prilaku peduli lingkungan dan tanggungjawab pada siswa madrasah. Menjawab hal tersebut, Salim (2015) menyatakan bahwa pendidikan karakter akan lebih efektif untuk dilaksanakan di madrasah dengan perencanaan, pengorganisasian, implementasi, pengawasan, dan evaluasi. Indikator dari kesuksesan pendidikan karakter dengan pendekatan manajemen adalah meningkatnya pengetahuan siswa terhadap nilai karakter, merasakan kebermanfaatan dari nilai karakter, dan mampu melakukan nilai karakter [5]. Nuryasin dan Mitrohardjono (2019) mengemukakan perencanaan pendidikan yang meliputi identifikasi masalah atau pekerjaan yang akan dilakukan, yaitu dengan mengusahakan peran pendidikan untuk mengembangkan moral dan mengendalikan tingkah laku siswa [6]. Setiawati (2020) dan Abin (2017) mengemukakan suatu pendekatan manajemen strategi dalam meningkatkan kualitas pendidikan, disebutkan bahwa pendidikan akan menjadi lebih baik dan lebih bermutu dengan pendekatan manajemen strategis [7].

Penelitian ini berkontribusi pada pencapaian visi-misi lembaga pendidikan dengan menggunakan pendekatan Manajemen Strategi. Visi-misi lembaga perlu untuk diturunkan pada program dan kegiatan yang akan dilakukan. Sinergi visi-misi dengan program, membantu lembaga mengaktualisasikan, merepresentasikan, pada pencapaian tujuan yang direncanakan. Pembentukan karakter merupakan salah satu tujuan pendidikan, yang membutuhkan pedoman dan langkah strategis untuk pelaksanaan kegiatan yang terencana dan terukur.

Prilaku peduli lingkungan dan tanggungjawab dapat ditumbuhkan dalam diri peserta didik melalui kegiatan menjaga kebersihan. Penelitian ini dilakukan dengan tujuan untuk memberikan deskripsi atau mendeskripsikan upaya yang dilakukan oleh madrasah dalam mewujudkan visi-misi yang dirumuskan dalam hal prilaku peduli lingkungan dan tanggungjawab melalui pendekatan manajemen strategis. Dengan penelitian ini diharapkan ditemukan suatu bentuk upaya yang sistematis memanfaatkan pendekatan manajemen strategis dalam menyusun kegiatan peduli lingkungan dan tanggungjawab melalui program kebersihan.

\section{Metode}

Metode untuk menjawab masalah penelitian menggunakan pendekatan kualitatif, dengan jenis metode deskriptif. Dengan tujuan penelitian mendeskripsikan upaya membentuk prilaku peduli lingkungan dan tanggungjawab santri perspektif manajemen strategi, pendekatan dan metode tersebut sangat relevan. Cresswell (2017) mengatakan tentang kedalaman yang dimunculkan pada penelitian kualitatif ini lebih berhubungan dengan kekayaan informasi dan kecocokan konteks apa yang ingin diketahui oleh peneliti daripada tergantung pada jumlah sampel [8].

Pendekatan penelitian yang digunakan pada penelitian ini adalah pendekatan penelitian kualitatif, yang mana peneliti dapat mengeksplorasi dan memotret fenomena, untuk kemudian disusun dan dikumpulkan sehingga menjadi pengetahuan. Adapun jenis penelitian yang dipilih adalah penelitian studi kasus. Pemilihan ini didasari pada tujuan yang diharapkan dalam menjawab rumusan masalah penelitian yang direncanakan.

Lokus penelitian ini adalah Madrasah Aliyah Darussalam Sengon Jombang, madrasah ini berbasis pesantren, subjek penelitian ini adalah santri, pengurus, wakil kepala sekolah bidang kesiswaan, guru Bimbingan dan Konseling, dan guru-guru di lokasi penelitian. Waktu penelitian dilaksanakan pada semester gasal tahun pembelajaran 2019-2020. Fokus penelitian ini pada upaya membentuk prilaku peduli lingkungan dan tanggungjawab dengan perspektif manajemen strategis.

Penggalian data dilakukan dengan proses mengamati dan mendengarkan penuturan informan terkait dengan objek penelitian. Teknik yang digunakan yaitu teknik observasi dan teknik wawancara. Tekinik observasi langsung dilakukan dengan turun langsung ke lapangan untuk mengamati prilaku dan aktifitas di lokasi penelitian [8]. Peneliti melakukan pengamatan ke seluruh area madrasah terhadap kegiatan yang berhubungan dengan upaya membentuk prilaku peduli lingkungan dan tanggung jawab santri. Wawancara digunakan oleh peneliti untuk menginteraksikan data yang didapatkan dari hasil observasi dan data wawancara bersama informan.

Teknik analisis data yang digunakan adalah menggunakan model analisis data dari Miles and Huberman yang meliputi tahapan-tahapan; reduksi data, penyajian data, verifikasi data yang 
dilakukan secara interaktif [9]. Untuk menjamin keabsahan data, peneliti menggunakan model Triangulasi yang mencakup tiga sumber yaitu data, metode, dan informan.

\section{Hasil dan Diskusi}

\subsection{Upaya pengelola dalam membentuk prilaku peduli lingkungan dan tanggungjawab siswa}

Kemenag Jawa Timur melakukan upaya untuk menjaga kualitas madrasah dengan Gerakan Ayo Membangun Madrasah yang disingkat dengan GERAM yang memiliki perhatian pada bidang literasi, kesehatan, inovatif, Furudhul Ainiyah, pengembangan kompetensi guru, pengingkatan kompetensi kepala madrasah, dan peningkatan kompetensi pengawas. Berbagai program ini menjadi daya tarik bagi madrasah untuk meningkatkan kualitasnya. Kemenag Kabupaten Jombang, memilih dan mengusung program kebersihan lingkungan sebagai andalan bagi madrasah-madrasah yang berada pada lingkup dan cakupannya. Program kebersihan lingkungan merupakan program yang sederhana, akan tetapi memiliki efek berantai yang luas terhadap siswa dan lingkungan. Selain dariipada itu kegiatan ini dapat mengembangkan karakter siswa yang peduli dan bertanggungjawab terhadap lingkungan.

Lingkungan madrasah yang bersih, indah, dan rapi merepresentasikan kepedulian dan tanggungjawab warga madrasah. Sebaliknya, kondisi madrasah yang kotor, banyak sampah bertebaran, merupakan representasi warga sekolah yang tidak peduli terhadap lingkungannya, dan tidak bertanggungjawab. Kondisi ini berimplikasi pada penilaian masyarakat terhadap madrasah, baik atau buruk mempengaruhi minat dan kepercayaan masyarakat terhadap madrasah.

Madrasah sebagai tempat berinteraksi antara siswa, siswa dengan guru, memiliki pola hidup yang hampir sama dengan kehidupan bermasyarakat di suatu daerah. Para siswa mempelajari keilmuan, makan dan minum, serta melakukan berbagai aktifitas dan kegiatan banyak ditemukan di madrasah. Kebutuhan energi menjadi hal yang sangat penting bagi siswa, untuk itu para siswa membeli makanan dan minuman di kantin madrasah atau warung warga sekitar. Makanan dan minuman yang dibeli dan dikonsumsi, menyisakan bungkus yang terbuat dari bahan organik maupun non organik. Bungkus habis pakai ini selanjutnya menjadi sampah. Sampah tersebut kemudian ditinggalkan atau dibuang dengan tidak pada tempatnya, sehingga menyebabkan permasalahan kebersihan di madrasah dan lingkungan sekitar. Sampah yang berserakan bisa saja berada di berbagai tempat, tetapi juga tidak jarang sudah berada di sekitar tempat sampah, namun tidak tepat, dengan kata lain yaitu tidak di dalam tempat sampah, melainkan di sekitarnya.

Pihak madrasah telah berupaya dengan memfasilitasi tempat sampah di berbagai tempat, namun beberapa sampah masih berserakan. Demikian itu merupakan dampak dari kecenderungan siswa yang bergantung pada petugas piket dan petugas kebersihan yang memiliki kewajiban menjaga kebersihan kelas dan lingkungannya. Kondisi yang demikian itu ditangkap oleh beberapa guru yang menyatakan bahwa prilaku yang demikian itu merupakan spiral negatif dari karakter tidak peduli dan bertanggungjawab terhadap lingkungan dan masyarakat.

Dalam rangka menumbuhkan perilaku peduli lingkungan dan tanggung jawab siswa terhadap lingkungan. Guru-guru bersepakat bersama kepala sekolah untuk membuat kebijakan membuang sampah pada tempatnya dengan kegiatan yang dinamakan "Kresekisasi". Kegiatan ini adalah kegiatan yang dilakukan bagi setiiap siswa madrasah Aliyah Darussalam Ngesong untuk membawa kantong plastik (Kresek), ke mana saja dan di mana saja. Kantong ini memiliki fungsi agar sampah kering yang dihasilkan atau didapatkan oleh siswa dapat dikumpulkan dan dibuang secara bersamasama ke tempat sampah. Selain daripada itu, guru-guru dapat menegur siswa untuk memperhatikan dan membersihkan sampah yang ada di sekitarnya untuk diambil dan dibuang pada tempatnya.

Program Kresekisasi muncul sebagai respon terhadap kecenderungan siswa madrasah yang lepas tanggungjawab terhadap kebersihan kelas dan lingkungan sekolah. Para siswa berasumsi bahwa kebersihan merupakan tanggungjawab petugas piket dan petugas kebersihan. Ketergantungan dan pelepasan tanggungjawab pada petugas piket dan petugas kebersihan dalam hal kebersiihan bertolak belakang dengan upaya madrasah dalam membentuk karakter siswa yang peduli dan turut bertanggungjawab terhadap lingkungan. 
Rencana kegiatan dilakukan dengan menginstruksikan kepada siswa untuk memiliki dan membawa kantong plastic ke manapun ia berada. Kewajiban ini dilakukan dengan harapan agar setiap siswa menyimpan dan memabawa sampah non organik atau sampah kering yang dimilikinya pada kantong plastik yang dia bawa. Untuk memastikan ketersediaan kantong plastik, pihak madrasah bekerjasama dengan unit Kantin siswa agar menyediakan kantong plastik. Selain daripada itu, untuk mendukung program tersebut, dilakukan pembatasan tempat sampah yang disediakan. Tempat sampah di sekolah disediakan di beberapa tempat yang terpusat, yaitu di depan kantor madrasah, dan satu tempat sampah pada setiap gedung bangunan madrasah. Pembatasan ini dimaksudkan agar para siswa membuang sampah secara langsung pada pembuangan sampah akhir. Demikian itu untuk membangun rasa peduli dan tanggungjawab siswa atas sampah non organik yang dihasilkannya.

Sosialisasi kegiatan dilakukan pada beberapa kegiatan yaitu; 1) Pada saat pembukaan tahun ajaran baru yang dihadiri oleh pengurus Yayasan, guru-guru madrasah, tenaga kependidikan, dan siswa; 2) Sosialisasi dilakukan secara berkelanjutan pada beberapa kegiatan upacara madrasah; 3) Sosialisasi dilakukan oleh wali kelas pada jam pelajaran atau tatap temu dengan siswa; 4) Guru-guru madrasah diberikan tugas untuk mengingatkan para siswa agar membiasakan menjaga kebersihan dengan membawa kantong plastik, mengumpulkan sampah yang dimiliki pada kantong plastik yang dimiliki, dan membuangnya pada pembuangan sampah akhir; dan 5) Guru-guru dimohon untuk mensosialisasikan dan mengkonstruksi pemahaman siswa untuk peduli dan bertanggungjawab terhadap lingkungan.

Pada pelaksanaannya, para siswa membawa kantong plastik ke manapun berada, guru-guru melakukan pemeriksaan, mengkontrol dan memastikan bahwa setiap siswa membawa, serta menggunakan kantong tersebut untuk menyimpan sampah non organik yang digunakannya, kemudian membuangnya pada pembuangan sampah akhir. Bagi beberapa siswa yang tidak membawa kantong plastik, guru-guru mengingatkan dan memerintahkan siswa tersebut untuk mengambil di asrama tempat para siswa tinggal. Siswa yang ditemukan tidak menjalankan dan melaksanakan program ini, akan dicatat dan ditulis pada buku pribadi siswa sebagai pelanggaran terhadap tata tertib.

Evaluasi kegiatan ini dilakukan secara periodik; harian, mingguan, dan pada moment-moment tertentu. Evaluasi harian dilakukan oleh para guru pada saat perkumpulan harian doa bersama di ruang guru. Evaluasi mingguan dilakukan kepada para siswa pada hari Senin, pada kegiatan upacara. Pada momen-moment tertentu seperti selesai shalat Dhuha, setelah shalat berjama'ah, para siswa diingatkan dan dievaluasi atas kepedulian dan tanggungjawabnya terhadap lingkungan madrasah. Demikian dengan harapan, agar para siswa memiliki prilaku dan akhlak yang tidak berhenti pada pengetahuan, tetapi juga menjadi suatu bagian dari dirinya dan menjadi kebiasaan.

Setelah dilaksanakan program ini dalam beberapa minggu dan bulan, tumbuh dalam diri siswa suatu persepsi bahwa sampah organik yang mereka hasilkan adalah merupakan tanggungjawab pribadi masing-masing untuk menjaganya dan mengantarkannya pada tempat sampah atau tempat pembuangan sampah akhir. Problem kebergantungan para siswa kepada petugas piket kebersihan kelas, dan petugas kebersihan lingkungan madrasah menjadi teratasi. Suasanan lingkungan yang dijaga kebersihannya secara bersama-sama, menjadikan para siswa memiliki rasa peduli dan tanggunjgawab yang tinggi. Beberapa siswa, saling mengingatkan satu sama lain untuk membawa sampah yang dihasilkan oleh temannya, dan membuang sampah pada tempat pembuangan akhir.

Upaya pembentukan prilaku peduli lingkungan dan tanggungjawab dilakukan oleh sekolah dengan menginsert nilai kebersihan. Lickona (2016) mengemukakan bahwa dalam menginternalisasikan nilai-nilai dilakukan dengan melalui proses moral knowing, moral feeling, dan moral action [10]. Moral knowing ditunjukkan dengan upaya guru-guru dalam memberikan pelajaran kebersihan yang penting bagi seluruh siswa, moral feeling nampak pada rasa bersama untuk menjaga kebersihan untuk kehidupan bersama yang nyaman dan bersih, adapun moral action nampak pada Gerakan Kresekisasi untuk meminimalisir penyebaran sampah, dan pengurangan penggunaan plastik. Senada dengan pendapat tersebut adalah disampaikan oleh Tafsir (2010) yang mensintesakan pembentukan karakter melalui tahapan-tahapan knowing, doing, dan being [11]. Suriasumantri (2017) mengemukakan bahwa untuk menginternalisasikan nilai-nilai yang berimplikasi pada prilaku, dibutuhkan upaya terorganisir dari penentuan nilai dan organisasi nilai [12]. Nilai kebersihan yang membentuk prilaku peduli lingkungan dan tanggungjawab dipilih oleh 
pengurus, kemudian dalam mengorganisasikan nilai tersebut, pengurus melakukan gerakan kresekisasi dari mulai pembentukan kebijakan, sosialisasi nilai dan kegiatan, pengawasan, dan diberikan reward juga punishment.

\subsection{Implementasi manajemen strategis dalam membangun prilaku peduli lingkungan dan tanggungjawab}

Manajemen strategik merupakan suatu proses formulasi dan implementasi rencana kegiatan yang berhubungan dengan hal yang penting dan dilakuksan secara berkesinambungan pada suatu organisasi. Implementasi manajement strategik penting untuk dilaksanakan pada lembaga pendidikan Islam, sehingga mampu mengalokasikan sumber daya yang ada dalam rangka mencapai tujuan penddikan [13]. Analisis SWOT dalam manajemen strategis untuk merumuskan formulasi dan rencana implementasi efektif dilakukan untuk membangun mutu sekolah yaitu siswa yang memilik karakter [14].

Prilaku peduli lingkungan dan tanggungjawab merupakan hasil dari strategi penanaman nilainilai pendidikan Islam pada peserta didik. Strategi tersebut dilakukan dengan model keteladanan, pembiasaan, nasehat atau bimbingan, dan hukuman [15]. Senada dengan hal tersebut di sampaikan oleh Dalimunthe (2015) yang menyebutkan bahwa strategi pendidikan karakter dilakukan dengan integrasi nilai dan etika pada proses pembelajaran, internalisasi nilai, pembiasaan dan latihan, keteladanan, penciptaan suasana, dan pembudayaan. Internalisasi nilai akan efektif dengan memberdayakan pendekatan manajemen strategis [16].

Madrasah Aliyah Darussalam Ngesong Jombang memiliki visi "Mulia dalam budipekerti, Unggul dalam Prestasi. Mulia dalam budipekerti diturunkan oleh pengelola madrasah di antaranya adalah dengan menginternalisasikan nilai peduli pada lingkungan dan tanggungjawab. Prilaku peduli lingkungan dan tanggungjawab siswa dilakukan dengan melakukan analisis internal dan eksternal madrasah yang memberikan data-data dan informasi kondisi siswa dan lingkungan sekolah. Untuk itu direncanakan program atau kegiatan yang relevan dengan kehidupan sehari-hari. Ide yang muncul adalah menyusun program "Kresekisasi".

Berdasarkan data observasi yang didapatkan di lapangan penelitian, disimpulkan analisis SWOT untuk pembentukan karakter peduli lingkungan dan tanggungjawab, dilakukan beberapa pertimbangan berikut;

Stregth-Weakness

a) Para siswa memiliki ketergantungan yang tinggi terhadap petugas piket kelas dan petugas kebersihan sekolah dalam menjaga kebersihan lingkungan

b) Kantin siswa merupakan tempat yang potensiil menjadi lokasi datangnya siswa untuk mendapatkan makanan dan membawa sampah.

c) Budaya sekolah yang meyakini konsepsi hifdzhu al-Biah dalam hal ini adalah keyakinan akan keharusan menjaga lingkungan dengan menjaga kebersihan merupakan bagian dari keimanan.

d) Madrasah memiliki waktu-waktu seremonial yang disepakati bersama, sehingga dimungkinkan untuk melakukan sosialisasi, monitoring, dan evaluasi.

\section{Opportunity-Treatment}

a) Program pemerintah dalam hal ini adalah Kementrian Agama Kantor Wilayah Provinsi Jawa Timur menyebutkan bahwa Gerakan Madrasah Sehat (GEMAS) merupakan salah satu upaya untuk meningkatkan atau membangun madrasah.

b) Ketidak pedulian dan tanggungjawab siswa terhadap lingkungan sekolah yang bersih akan berdampak pada kondisi sekolah yang kumuh dan kotor, demikian itu berimplikasi pada penilaian masyarakat terhadap madrasah.

Berdasarkan analisis internal dan eksternal tersebut, dirumuskan formulasi strategi yang akan dilakukan yaitu; 
1.Program pemerintah terkait GEMAS dimanfaatkan oleh madrasah dengan memberdayakan budaya sekolah yang relevan dengan kegiatan tersebut.

2.Program pemerintah terkait GEMAS dimanfaatkan oleh madrasah dengan meminimalisir kelemahan siswa madrasah yang memiliki ketergantungan yang tinggi terhadap petugas piket dan petugas kebersihan sekolah.

3.Ketidakpedulian dan lemahnya tanggungjawab siswa yang berdampak minat dan penilaian yang rendah kepada madrasah ditegaskan untuk menghilangkan ketergantungan pada petugas piket dan tenaga kebersihan.

4.Ketidakpedulian dan lemahnya tanggungjawab siswa yang berdampak minat dan penilaian yang rendah kepada madrasah dapat diminimalisir dan dikendalikan dengan mengoptimalkan budaya madrasah, sarana dan prasarana madrasah, dan optimalisasi kegiatan seremonial untuk sosialisasi kegiatan.

Upaya pengelola madrasah untuk mewujudkan visi-misi dan tujuan internalisasi karakter dilakukan dengan melakukan analisis internal dan analisis eksternal. Perbandingan antara analisis internal dan eksternal tersebut dikembangkan dengan menggunakan analisis SWOT. Yunus (2016) menyebutkan bahwa analisis lingkungan internal dalam bingkai SWOT merupakan uraian tentang dimensi kekuatan atau Streght dan kelemahan atau Weakness, sedangkan analisis eksternal dilakukan dengan uraian tentang peluang atau Opportunity dan ancaman atau Threatment [17].

Berdasarkan uraian tentang kekuatan, kelemahan, peluang, dan ancaman dirumuskan strategi dengan pertimbangan dan perbandingan sebagai berikut;

1.Strategi memanfaatakan peluang yang ada dengan mengoptimalkan kekuatan (O-S).

2.Strategi memanfaatkan peluang yang ada dengan memperbaiki kelemahan (O-W).

3.Strategi mengatasi ancaman dengan menjauhkan kelemahan (T-W).

4.Strategi mengatasi ancaman dengan menggunakan kekuatan (T-W) (Yunus, 2016; 86).

Formulasi strategi yang telah direncanakan madrasah tersebut, berimplikasi pada efektifitas implementasi strategi. Yunus (2016) menyebutkan kriteria implementasi strategis yang terdiri dari; 1) Mengelola kekuatan yang meliputi semua aspek selama tindakan dijalankan; 2) fokus pada efisiensi; 3) merupakan proses operasional; 4) membutuhkan motivasi khusus dan keahlian kepemimpinan; dan 5) membutuhkan koodrinasi di antara banyak individu [17].

Pada praktiknya di madrasah, rencana strategis yang telah diformulasikan dilakukan oleh guruguru dan tenaga kependidikan bersama para siswa. Kegiatan yang dilakukan adalah menjalankan program Kresekisasi untuk menginternalisasikan nilai peduli lingkungan dan tanggungjawab. Untuk itu, dilakukan pengembangan program dan penyusungan prosedur kegiatan. Para guru dan pengelola sekolah bertanggungjawab terhadap implementasi program, kegiatan-kegiatan pengawasan dan pengarahan menjadi bagian yang penting dalam mensosialisasikan dan meningkatkan efektifitas program.

\section{Kesimpulan}

Upaya guru-guru dan pengelola sekolah dalam membentuk prilaku peduli lingkungan dan tanggungjawab menjadi hal yang penting dalam membentuk karakter siswa. Hasil penelitian menunjukkan upaya tersebut dilakukan dengan kegiatan Kresekisasi. Pengambilan keputusan pelaksanaan kegiatan dilakukan merupakan realisasi strategi dari visi pesantren yang mulia dalam budi pekerti dan unggul dalam prestasi menanggapi kondisi eksternal dan internal madrasah berbasis pesantren. Realisasi ini dilakukan dengan mengimplementasikan proses strategi yaitu; pengumpulan informasi dan data, pengembangan strategi, implementasi strategi, dan pengukuran serta hasil kegiatan. Pembentukan prilaku peduli lingkungan dan tanggungjawab diimplementasikan dalam suatu proses manajemen strategis, yang mendukung pembentukan karakter.

Pada penelitian yang akan datang, masih menjadi peluang untuk dilakukan penelitian terkait implementasi manajemen strategis dalam pengembangan sekolah dan penyusunan program. Demikian itu menjadi penting, agar fungsi perencanaan kegiatan dapat maksimal dilakukan, dan 
meminimalisir potensi kegagalan. Keterbatasan pada penelitian ini adalah pada aspek implementasi strategi, dan evaluasi strategi yang belum banyak diakomodasi pada penelitian ini.

\section{Ucapan Terimakasih}

Terimakasih disampaikan oleh peneliti kepada guru-guru dan pengasuh Madrasah Aliyah Darussalam Ngesong Jombang, atas bantuan dan kerjasamanya pada pelaksanaan penelitian yang telah dilakukan. Terimakasih juga disampaikan kepada dosen pengampu mata kuliah Manajemen Strategis Prof. Dr. Widji Astuti, MM., dan H. Slamet, M.M., M.Pd, Ph.D.

\section{Referensi}

[1] A. Mukminin, "STRATEGI PEMBENTUKAN KARAKTER PEDULI LINGKUNGAN DI SEKOLAH ADIWIYATA MANDIRI," Ta'dib: Jurnal Pendidikan Islam, vol. 19, no. 02, pp. 203-226, Nov. 2014.

[2] A. M. Rosyad, "The Urgency of Learning Innovation On Islamic Religious Study," AlAfkar: Journal of Islamic Studies, vol. 3, no. No. 1, pp. 64-86, 2019.

[3] M. A. Nugroho, H. Hariyanto, and E. Suharini, "PERILAKU PEDULI LINGKUNGAN SISWA SEKOLAH ADIWIYATA PERDESAAN DAN PERKOTAAN DI JAWA TENGAH TAHUN 2016," Edu Geography, vol. 5, no. 2, pp. 26-34, 2017.

[4] S. D. Ardianti, S. Wanabuliandari, and S. Rahardjo, "PENINGKATAN PERILAKU PEDULI LINGKUNGAN DAN TANGGUNG JAWAB SISWA MELALUI MODEL EJAS DENGAN PENDEKATAN SCIENCE EDUTAINMENT," Jurnal Ilmiah Pendidikan Dasar, vol. 4, no. 1, pp. 01-07, 2017.

[5] A. Salim, "MANAJEMEN PENDIDIKAN KARAKTER DI MADRASAH," Tarbawi: Jurnal Keilmuan Manajemen Pendidikan, vol. 1, no. 2, pp. 1-16, 2015.

[6] M. Nuryasin and M. Mitrohardjono, "STRATEGI PERENCANAAN PENGEMBANGAN PENDIDIKAN ISLAM DI INDONESIA," Jurnal Tahdzibi: Manajemen Pendidikan Islam, vol. 4, no. 2, pp. 77-84, 2019.

[7] F. Setiawati, "Manajemen Strategi untuk Meningkatkan Kualitas Pendidikan," Jurnal AtTadbir : Media Hukum Dan Pendidikan, vol. 30, no. 01, pp. 57-66, 2020.

[8] J. W. Cresswell, Research Design; Pendekatan Kualitatif, Kuantitatif, dan Mixed, 3rd ed. Yogyakarta: Pustaka Pelajar, 2017.

[9] S. Sugiyono, Metode Penelitian Pendidikan. Bandung: Alfabeta, 2019.

[10] T. Lickona, Educating for character: Mendidik untuk membentuk karakter. Jakarta: Bumi Aksara, 2016.

[11] A. Tafsir, Filsafat Pendidikan Islami; Integrasi Jasmani, Rohani, dan Kalbu. Bandung: P.T. Remaja Rosdakarya, 2010.

[12] J. S. Suriasumantri, Filsafat Ilmu; Sebuah Pengantar Populer Keterkaitan Ilmu, Agama, dan Seni. Jakarta: P.T. Sinar Harapan, 2017.

[13] A. Khori, "Manajemen Strategik dan Mutu Pendidikan Islam," MANAGERIA: Jurnal Manajemen Pendidikan Islam, vol. 1, no. 1, Apr. 2018, doi: 10.14421/manageria.2016.11-05.

[14] E. Sujoko, "STRATEGI PENINGKATAN MUTU SEKOLAH BERDASARKAN ANALISIS SWOT DI SEKOLAH MENENGAH PERTAMA," Kelola: Jurnal Manajemen Pendidikan, vol. 4, no. 1, pp. 83-96, Jun. 2017, doi: 10.24246/j.jk.2017.v4.i1.p83-96. 
[15] R. A. M. Ansori, "STRATEGI PENANAMAN NILAI-NILAI PENDIDIKAN ISLAM PADA PESERTA DIDIK”," JURNAL PUSAKA, vol. 4, no. 2, pp. 14-32, 2017.

[16] R. A. Abdillah Dalimunthe, "STRATEGI DAN IMPLEMENTASI PELAKSANAAN PENDIDIKAN KARAKTER DI SMP N 9 YOGYAKARTA,” Jurnal Pendidikan Karakter, no. 1, pp. 102-111, Apr. 2016, doi: 10.21831/jpk.v0i1.8616.

[17] E. Yunus, Manajemen Strategis. Yogyakarta: C.V. Andi Offset, 2016. 